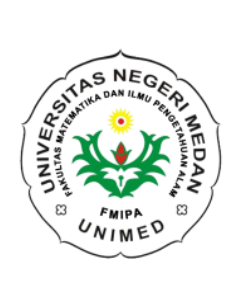

Jurnal Inovasi Pembelajaran Fisika

(INPAFI)

Available online http://jurnal.unimed.ac.id/2012/index.php/inpafi

e-issn 2549-8258, p-issn 2337-4624

\title{
PENGARUH MODEL PEMBELAJARAN DISCOVERY LEARNING TERHADAP HASIL BELAJAR SISWA PADA MATERI POKOK MOMENTUM, IMPUSLS DAN TUMBUKAN KELAS X SEMESTER II DI SMA N 1 PANCURBATU TP. 2016/2017
}

\author{
Jujur Monasari Simatupang dan Pintor Simamora \\ Jurusan Fisika FMIPA Universitas Negeri Medan \\ monasari46@gmail.com,pintor_fisika@yahoo.co.id
}

Diterima: September 2018. Disetujui: Oktober 2018. Dipublikasikan: Nopember 2018

\begin{abstract}
ABSTRAK
Penelitian ini bertujuan untuk mengetahui pengaruh penggunaan model discovery learning terhadap hasil belajar siswa pada materi pokok momentum, impuls dan tumbukan. Jenis penelitian ini adalah quasi experimen dengan populasi seluruh siswa kelas X SMA Negeri 1 Pancurbatu yang berjumlah 5 kelas. Sampel penelitian ini terdiri dari 2 kelas yang ditentukan dengan teknik random sampling, yaitu kelas X MIA 5 dengan menggunakan model pembelajaran discovery dan kelas X MIA 4 dengan menggunakan model pembelajaran konvensional. Instrumen yang digunakan adalah esai tes sebanyak 5 soal yang telah dilakukan uji persyaratan tes. Data rata-rata pretes kelas eksperimen dan kelas kontrol adalah 41,35 dan 41,25 . Kedua kelas mempunyai kemampuan awal yang sama. Selanjutanya nilai rata-rata postes kelas eksperimen 71,48 dan kelas kontrol 54,16. Uji normalitas dan homogenitas menunjukkan bahwa kedua kelas berdistribusi normal dan homogen. Kemudian uji hipotesis membuktikan bahwa ada perbedaan yang signifikan akibat pengaruh model pembelajaran discovery learning terhadap hasil belajar siswa. Akhirnya dapat disimpulkan bahwa model pembelajaran discovery learning berpengaruh terhadap hasil belajar siswa pada materi pokok momentum, impuls dan tumbukan di kelas X semester II SMA Negeri 1 Pancur Batu T.P 2016/2017
\end{abstract}

Kata Kunci : discovery learning, hasil belajar

\begin{abstract}
This study aims to determine the influence of discovery learning model on student's achievement of momentum, impuls and collision. The type of this study is quasi experiment with the population are all the students class X in SMA N I Pancurbatu consist of 5 classes. Sample of this study cocsists of two classes which is determined by random sampling technique, namely $X$ MIA-5 by using discovery learning model and $X$ MIA 4 using conventional learning model. The instrument used is an essay test of 5 questions that have
\end{abstract}


been tested test requirements. The average data of experimental class pretest and control class were 41,35 and 41,25. Both classes have the same initial ability. Furthermore the average grade of experimental class postes 71.48 and control class 54.16. Normality and homogeneity tests show that both classes are normal and homogeneous distributed. Then test the hypothesis proves that there is a significant difference due to the influence of learning discovery learning model on student learning outcomes. Finally it can be concluded that the learning discovery learning model influences student learning outcomes on the subject matter of momentum, impulse and collision in class X second semester SMA Negeri 1 Pancur Batu T.P 2016/2017.

Keywords: discovery learning, learning outcomes

\section{PENDAHULUAN}

Pendidikan merupakan faktor yang sangat penting bagi kehidupan manusia. Melalui pendidikan, manusia akan tumbuh dan berkembang sebagai pribadi yang utuh. Pendidikan memegang peranan yang sangat penting dalam mempersiapkan manusia yang berkualitas bagi pembangunan negara. Menurut Sanjaya (2011:2) pendidikan adalah usaha sadar dan terencana untuk mewujudkan suasana belajar dan proses pembelajaran agar peserta didik secara aktif mengembangkan potensi dirinya untuk memiliki kekuatan spritual keagamaan, pengendalian diri, kepribadian, kecerdasan dan akhlak mulia, serta keterampilan yang diperlukan dirinya, masyarakat, bangsa, dan negara.

Pendidikan juga sangat erat kaitannya dengan Iptek. Berkembangnya pendidikan sudah pasti akan berpengaruh terhadap perkembangan Ilmu Pengetahuan dan Teknologi. Pesatnya perkembangan Ilmu pengetahuan dan Teknologi sekarang ini tidak dapat terlepas dari kemajuan Ilmu fisika yang banyak menghasilkan temuan baru dalam bidang sains dan teknologi. Fisika dalam hal ini ditempatkan sebagai salah satu mata pelajaran yang penting karena salah satu syarat penguasaan ilmu pengetahuan dan teknologi berhubungan dengan Ilmu Pengetahuan Alam (IPA) yang didalamnya termasuk fisika. Fisika merupakan suatu Ilmu pengetahuan yang mempelajari gejala-gejala alam dan interaksinya yang dapat dianfaatkan oleh manusia dan dalam keperluan hidupnya. Fisika merupakan objek mata pelajaran yang lebih menitikberatkan pada pemahaman daripada penghafalan siswa terhadap materi.

Fisika sebagai cabang Ilmu Pengetahuan Alam (IPA) merupakan objek mata pelajaran yang menarik dan lebih banyak memerlukan pemahaman daripada penghafalan. Kegiatan pembelajaran fisika lebih menekankan pada pemberian langsung untuk meningkatkan kompetensi agar siswa mampu berpikir kritis dan sistematis dalam memahami konsep fisika, sehingga siswa memperoleh pemahaman yang benar tentang fisika. Pemahaman yang benar akan pelajaran fisika sangat berpengaruh terhadap hasil belajar siswa. Fakta di lapangan menunjukkan bahwa aktivitas siswa dalam pelajaran fisika masih sangat kurang.

Berdasarkan hasil wawancara yang dilakukan dengan salah seorang guru bidang studi Fisika kelas X di SMA N 1 Pancurbatu mengatakan bahwa kendala dalam kegiatan belajar megajar fisika di 
SMA Negeri 1 Pancurbatu adalah tidak siapnya siswa dalam mengikuti proses pembelajaran fisika sehingga memicu rendahnya aktivitas siswa dalam mempelajari pelajaran fisika akibatnya siswa seringkali mengalami kebingungan dalam menyelesaikan soal-soal fisika. Siswa hanya dapat mengingat soal-soal di saat hari itu saja tetapi jika tiba saat ujian mereka tidak bisa mengerjakan soal-soal kembali. Hal ini membuat siswa hanya menghafal rumus dan bukan memahami konsep fisika untuk menyelesaikan soal saat menghadapi ujian. Hal tersebut juga mempengaruhi hasil belajar siswa dalam proses belajar mengajar khususnya mata pelajaran fisika yang masih belum mencapai KKM. KKM untuk mata pelajaran Fisika di SMA N 1 Pancurbatu adalah 70, sementara banyak siswa yang memperoleh nilai di bawah 70. Kendala lain yang dihadapi saat proses pembelajaran fisika yaitu siswa mudah lupa terhadap materi fisika yang diterangkan oleh guru. Siswa hanya mengingat pelajaran fisika pada saat diterangkan saja, dan ketika diberikan soal, siswa dominan lupa dan kesulitan saat mengerjakannya.

Berkaitan dengan uraian tersebut, maka perlu dipikirkan cara dan strategi untuk mengatasi permasalahan di atas. Salah satu model yang cocok diterapkan dalam belajar fisika adalah model discovery learning. Alasan ini didasarkan pada latar belakang masalah yang telah dikemukakan sebelumnya yakni siswa hanya mampu mengingat konsep fisika pada saat diterangkan saja dan proses pembelajaran hanya menekankan pada ingatan dan pemahaman materi pelajaran saja, sehingga kegiatan berpikir tidak dioptimalkan. Akibatnya, pengetahuan yang terbentuk tidak tahan lama yang berdampak pada hasil belajar siswa yang rendah. Model pembelajaran discovery learning

Melalui model pembelajaran discovery learning, permasalahan tersebut diharapkan dapat teratasi hal ini didasarkan karena model pembelajaran discovery learning : Hosnan (2014: 282) discovery learning adalah suatu model untuk mengembangkan cara belajar siswa aktif menemukan sendiri, menyelidiki sendiri, maka hasil yang diperoleh akan setia dan tahan lama dalam ingatan, tidak akan mudah dilupakan oleh siswa. Anak juga bisa belajar berpikir analisis dan mencoba memecahkan sendiri masalah yang dihadapi dengan belajar penemuan. Melalui model pembelajaran ini, siswa diharapkan menemukan sendiri dan mentransformasikan informasi kompleks, mengecek informasi baru dengan yang sudah ada dalam ingatannya, dan melakukan pengembangan menjadi informasi atau kemampuan yang sesuai dengan lingkungan dan zaman, tempat dan waktu ia hidup. Model pembelajaran discovery learning berpengaruh terhadap hasil belajar siswa, dimana dengan diterapkannya model pembelajaran discovery learning, siswa akan aktif menemukan dan menyelidiki sendiri konsep pembelajaran yang diajarkan guru sehingga hasil yang diperoleh siswa akan tahan lama dalam ingatannya dan tidak mudah dilupakan. Konsep pembelajaran yang telah mereka ingat akan berpengaruh terhadap hasil belajarnya. Misalnya, ketika menghadapi ujian siswa tidak lagi kebingungan dalam menghapal rumus fisika karena konsep pembelajaran telah mereka ingat sebelumnya. Mengetahui konsep lebih mudah dari menghapal rumus-rumus fisika. Penelitian mengenai model pembelajaran discovery learning sudah pernah diteliti oleh peneliti sebelumnya. Bahrani (2015) sebelum diberikan perlakuan rata-rata pretes 
sebesar 45,83 dan setelah diberikan perlakuan rata-rata postes siswa sebesar 75,33. Hal ini berarti bahwa model pembelajaran discovery learning dapat dikatakan efektif didalam pembelajaran tersebut. Begitu juga pada penelitian Habibi (2015) menggunakan model pembelajaran discovery learning sebesar 75,83 (sedang) dengan kriteria tuntas, dimana $80 \%$ siswa yang tuntas dan $20 \%$ siswa yang tidak tuntas.

\section{METODE PENELITIAN}

Penelitian ini menggunakan metode quasi eksperimen dengan desain two group pre-test dan pos-test. Populasi dalam penelitian ini adalah seluruh siswa kelas X SMA Negeri 1 Pancurbatu pada semester genap T.P. 2016/2017 yang terdiri dari 5 kelas.

Sampel dalam penelitian ini terdiri dari 2 kelas dimana pengambilan sampel dalam penelitian ini dipilih secara acak yaitu dengan menggunakan random sampling yakni setiap kelas populasi berhak memiliki kesempatan untuk menjadi sampel penelitian.

Satu kelas dijadikan sebagai kelas eksperimen yaitu kelas yang diberikan perlakuan dengan menerapkan model pembelajaran discovery dan satu kelas lagi dijadikan sebagai kelas kontrol dengan menerapkan model pembelajaran konvensional. Adapun kelas yang dijadikan sebagai kelas eksperimen adalah kelas X MIA-5 dengan jumlah siswa 37 orang dan kelas kontrolnya adalah kelas $\mathrm{X}$ MIA-4, dengan jumlah siswa adalah 36 orang.

Instrumen yang digunakan dalam penelitian ini adalah tes esai berjumlah 5 soal untuk pretes dan postes yang sebelumnya telah divalidasi oleh tiga orang validator. Selain tes hasil belajar, instrumen yang digunakan adalah lembar observasi aktivitas yang dikembangkan peneliti sendiri dengan memadupadankan fase-fase discovery learning.

Menurut Hosnan( 2014:289) langkah-langkah operasional (sintaks) model pembelajaran discovery learning terdiri dari: (1) stimulasi; (2) identifikasi masalah; (3) pengumpulan data; (4) pengolahan data; (5) pembuktian; (6) menarik kesimpulan. Aktivitas belajar yang baik menurut Paul Diedrich (Sardiman, 2007) meliputi : Visual activities, Oral activities, Listening activities, Writing activities, Drawing activities, Motor activities, Mental activities, dan Emotional activities.

Desain penelitian ini dengan $t w o$ group pretest-postest design dapat dilihat pada Tabel 1.

Tabel 1 : Two Group Pretest-Postest Design

\begin{tabular}{|l|c|c|c|}
\hline \multicolumn{1}{|c|}{ Kelas } & $\begin{array}{c}\text { Prete } \\
\mathrm{s}\end{array}$ & Perlakuan & $\begin{array}{c}\text { Poste } \\
\mathrm{s}\end{array}$ \\
\hline $\begin{array}{l}\text { Eksperime } \\
\mathrm{n}\end{array}$ & $\mathrm{T}_{1}$ & $\mathrm{X}$ & $\mathrm{T}_{2}$ \\
\hline Kontrol & $\mathrm{T}_{1}$ & $\mathrm{Y}$ & $\mathrm{T}_{2}$ \\
\hline
\end{tabular}

Keterangan:

$\mathrm{T}_{1}$ : Pemberian tes awal (pretes)

$\mathrm{T}_{2}$ : Pemberian tes akhir (postes)

$\mathrm{X}$ : Perlakuan dengan model pembelajaran discovery

Y : Perlakuan dengan modelpembelajaran konvensional

Hasil pretes yang diperoleh dilakukan uji normalitas, uji homogenitas dan uji kesamaan rata-rata (ujit) untuk mengetahui apakah data berdistribusi normal, homogen dan tidak ada perbedaan yang signifikan antara kemampuan awal kedua kelas. Selanjutnya kedua kelas diberi perlakuan yang berbeda dan postes diakhir pembelajaran.Hasil postes yang diperoleh dilakukani uji t satu pihak untuk melihat 
Jujur Monasari Simatupang dan Pintor Simamora : Pengaruh Model Pembelajaran Discovery

Learning Terhadap Hasil Belajar Siswa Pada Materi Pokok Momentum, Impusls Dan Tumbukan Kelas X Semester II Di SMA N 1 Pancurbatu TP. 2016/2017

ada tidaknya pengaruh penerapan model pembelajaran discovery.

\section{HASIL DAN PEMBAHASAN}

\section{A. Hasil Penelitian}

Tahap awal penelitian, kedua kelas yaitu kelas eksperimen dan kelas kontrol diberikan pretes yang bertujuan untuk melihat kemampuan awal belajar siswa pada kedua kelas tersebut. Berdasarkan data penelitian diperoleh nilai rata-rata pretes siswa kelas eksperimen sebelum diberi perlakuan sebesar 41,35 dengan standar deviasi 8,94, sedangkan kelas kontrol diperoleh nilai rata-rata pretes siswa 41,25 dengan standar deviasi 8,89. Kedua kelas diberikan perlakuan yang berbeda, yaitu menerapkan model pembelajaran discovery pada kelas eksperimen dan model pembelajaran konvensional pada kelas kontrol, kedua kelas selanjutnya diberikan postes yang bertujuan untuk melihat kemampuan akhir belajar siswa pada kedua kelas tersebut. Berdasarkan data penelitian,diperoleh nilai rata-rata postes siswa kelas eksperimen sebesar 71,48 dengan standar deviasi 11,65, sedangkan kelas kontrol diperoleh nilai rata-rata postes siswa 54,16 dengan standar deviasi 9,81 . Hasil penelitian ditunjukkan pada Tabel 2.

Tabel 2 :Hasil Pretes dan Postes Kelas Eksperimen dan Kelas Kontrol

\begin{tabular}{|c|c|c|c|c|}
\hline \multirow[t]{2}{*}{ Statistik } & \multicolumn{2}{|c|}{$\begin{array}{c}\text { Kelas } \\
\text { Eksperimen }\end{array}$} & \multicolumn{2}{|c|}{ Kelas Kontrol } \\
\hline & Pretes & Postes & Pretes & Postes \\
\hline $\begin{array}{c}\text { Nilai } \\
\text { Tertinggi }\end{array}$ & 60 & 90 & 60 & 80 \\
\hline $\begin{array}{c}\text { Nilai } \\
\text { Terenda } \\
\text { h }\end{array}$ & 20 & 50 & 20 & 35 \\
\hline Rata-rata & 41,35 & 71,48 & 41,25 & 54,16 \\
\hline $\begin{array}{l}\text { Standar } \\
\text { Deviasi }\end{array}$ & 8,94 & 11,65 & 8,89 & 9,81 \\
\hline
\end{tabular}

Hasil pretes siswa di kelas eksperimen dan kelas kontrol kemudian dianalisis berupa uji normalitas dengan uji liliefors, uji homogenitas data pretes dengan uji F, dan uji t. Hasil uji normalitas data pretes kedua kelas diperoleh Lhitung $<$ Ltabel pada taraf signifikan 0,05, kelas eksperimen $(0,1001<0,1476)$ dan kelas kontrol $(0,1115<0,1476)$ yang menunjukkan bahwa data pretes dari kedua kelas berdistribusi normal, dan dari hasil uji homogenitas diperoleh $\mathrm{F}_{\text {hitung }}<\mathrm{F}_{\text {tabel }}$ $(1,012<1,776)$ yang menunjukkan bahwa sampel yang digunakan dalam penelitian ini dinyatakan homogen atau dapat mewakili seluruh populasi yang ada.

Perhitungan data dengan menggunakan uji $t$, pretes kelas eksperimen dan kelas kontrol diperoleh thitung $=0,05$ dan tabel untuk $\alpha=0,05$ adalah 1,66 dimana thitung $<$ tabel yang artinya $\mathrm{H}_{\mathrm{o}}$ diterima dan $\mathrm{H}_{a}$ ditolak, sehingga dapat diperoleh kesimpulan bahwa kelas eksperimen dan kelas kontrol memiliki kemampuan awal yang sama. Tabel distribusi nilai pretes siswa disajikan pada Tabel 3.

Tabel 3 : Distribusi Nilai Pretes Siswa Kelas Eksperimen Dan Kelas Kontrol

\begin{tabular}{|c|c|c|c|c|c|c|}
\hline \multicolumn{4}{|c|}{ Kelas Eksperimen } & \multicolumn{3}{|c|}{ Kelas Kontrol } \\
\hline Nilai & $\begin{array}{l}\text { Fre } \\
\text { ku- } \\
\text { ensi }\end{array}$ & $\overline{\bar{X}}$ & $S$ & $\begin{array}{c}\text { Freku } \\
\text {-ensi }\end{array}$ & $\overline{\boldsymbol{X}}$ & $S$ \\
\hline 20 & 1 & \multirow{9}{*}{41,35} & \multirow{9}{*}{8,94} & 1 & \multirow{9}{*}{41,25} & \multirow{9}{*}{8,89} \\
\hline 25 & 2 & & & 2 & & \\
\hline 30 & 2 & & & 2 & & \\
\hline 35 & 7 & & & 6 & & \\
\hline 40 & 8 & & & 9 & & \\
\hline 45 & 7 & & & 7 & & \\
\hline 50 & 7 & & & 6 & & \\
\hline 55 & 2 & & & 2 & & \\
\hline 60 & 1 & & & 1 & & \\
\hline Jumlah & 37 & & & 36 & & \\
\hline
\end{tabular}


Kedua kelas diberikan perlakuan yang berbeda, dan diperoleh data postes, maka data dianalisis dengan melakukan uji t. Hasil analisis data diperoleh besar thitung $>$ tabel yaitu 6,97 > 1,668 dengan taraf signifikansi 5\%. Hal ini berarti bahwa ada pengaruh yang signifikan dari penerapan model pembelajaran discovery terhadap hasil belajar siswa pada materi momentum, impuls dan tumbukan pada kelas eksperimen, dengan kata lain $\mathrm{H}_{\mathrm{a}}$ diterima. Distribusi nilai hasil belajar siswa (postes) disajikan pada Tabel 4

Tabel 4. Distribusi nilai hasil belajar siswa (postes) kelas eksperimen dan kontrol

\begin{tabular}{|c|c|c|c|c|c|c|c|}
\hline \multicolumn{4}{|c|}{ Kelas Eksperimen } & \multicolumn{4}{|c|}{ Kelas Kontrol } \\
\hline Nilai & $\begin{array}{c}\text { Frek } \\
\text { uens } \\
\text { i }\end{array}$ & $\bar{X}$ & $\mathbf{S}$ & Nilai & $\begin{array}{c}\text { Fre } \\
\text { kue } \\
\text { nsi }\end{array}$ & $\bar{X}$ & $\mathbf{S}$ \\
\hline 50 & 3 & \multirow{9}{*}{$\begin{array}{l}71, \\
48\end{array}$} & \multirow{9}{*}{$\begin{array}{l}1 \\
1, \\
6 \\
5\end{array}$} & 35 & 2 & \multirow{9}{*}{54,16} & \multirow{9}{*}{$\begin{array}{l}9, \\
81\end{array}$} \\
\hline 55 & 1 & & & 40 & 2 & & \\
\hline 60 & 6 & & & 45 & 2 & & \\
\hline 65 & 2 & & & 50 & 10 & & \\
\hline 70 & 9 & & & 55 & 9 & & \\
\hline 75 & 2 & & & 60 & 6 & & \\
\hline 80 & 8 & & & 65 & 3 & & \\
\hline 85 & 2 & & & 80 & 2 & & \\
\hline 90 & 4 & & & & & & \\
\hline Jumlah & 37 & & & $\begin{array}{l}\text { Jum } \\
\text { lah }\end{array}$ & 36 & & \\
\hline
\end{tabular}

\section{B. Pembahasan}

Hasil penelitian menunjukkan bahwa ada pengaruh yang signifikan menggunakan model discovery learning terhadap hasil belajar siswa pada materi pokok momentum, impuls dan tumbukan kelas $\mathrm{X}$ Semester II di SMA $\mathrm{N} \quad 1$ Pancurbatu. Hasil penelitian terhadap kelas eksperimen menggunakan model discovery learning terhadap hasil belajar siswa pada materi pokok momentum, impuls dan tumbukan menunjukkan adanya peningkatan hasil belajar yang signifikan. Hal ini ditunjukkan dengan meningkatnya hasil belajar siswa dari nilai rata-rata pretes kelas eksperimen sebesar
41,35 dan tidak ada seorang pun siswa yang lulus KKM sebesar 70 menjadi 71,48 pada nilai rata- rata postes. Hasil penelitian terhadap kelas kontrol dengan menggunakan model pembelajaran konvensional juga menunjukkan adanya peningkatan hasil belajar. Hal ini ditunjukkan dengan meningkatnya hasil belajar siswa dari nilai rata-rata pretes kelas kontrol sebesar 41,25 dan tidak ada seorang pun siswa yang mencapai KKM sebesar 70 menjadi sebesar 54,16 pada nilai rata-rata postes.

Berdasarkan uraian di atas, maka hasil penelitian ini menunjukkan adanya perbedaan model discovery learning dengan model pembelajaran konvensional terhadap hasil belajar siswa. Adanya perbedaan hasil belajar yang signifikan antara kelas ekperimen dan kelas kontrol disebabkan oleh penggunaan model discovery learning pada kelas eksperimen. Model discovery learning yang memiliki sintaks-sintaks atau fase-fase dalam pembelajaran yang tidak dimiliki oleh pembelajaran konvensional. Model discovery learning menekankan kepada proses keterlibatan siswa secara penuh untuk dapat menemukan materi yang dipelajari dan menghubungkannya dengan situasi kehidupan nyata sehingga mendorong siswa untuk dapat menerapkannya dalam kehidupan seharihari, dalam proses pembelajaran discovery learning siswa tidak hanya berperan sebagai penerima pelajaran melalui penjelasan guru secara verbal, tetapi siswa berperan untuk menemukan sendiri inti dari materi pelajaran. Keaktifan siswa dalam pembelajaran dengan menggunakan model discovery learning merupakan suatu proses yang bermula dari tahap stimulasi, identifikasi masalah, pengumpulan data, pengolahan data, verifikasi dan generalisasi. Langkah- 
langkah pembelajaran tersebut mendorong siswa untuk lebih aktif di dalam kelas.

Ditinjau dari hasil belajar siswa yang diperoleh selama penelitian, ranah kognitif C1, C2, C3, C4 dan C5, dalam ranah kognitif C1 (mengingat) selama penelitian, peneliti tidak secara langsung menyebutkan pokok-pokok permasalahan yang relevan dengan materi pembelajaran, melainkan peneliti menggali pengetahuan siswa, memotivasi siswa untuk berpikir aktif supaya dapat menemukan sendiri pokok permasalahan tersebut. Hal ini memacu siswa agar terbiasa menemukan sendiri dan hasil yang ditemukannya tahan lama alam ingatan dan tidak mudah lupa. Hal ini didukung oleh pendapat Kadri dan Rahmawati, 2015 dalam jurnal penelitian yang menyatakan bahwa model discovery learning adalah suatu model untuk mengembangkan cara belajar siswa aktif dengan menemukan sendiri informasi maka hasil yang diperoleh tidak mudah dilupakan siswa. Model discovery learning membuat siswa lebih aktif dalam belajar, karena dengan model ini maka pengetahuan dan keterampilan yang diperoleh oleh siswa diharapkan bukan hasil mengingat seperangkat fakta-fakta, tetapi hasil dari menemukan sendiri. Model ini juga membuat siswa dapat bekerja sama dalam kelompok. Tingkat pemahaman yang diperoleh siswa lebih mendalam karena siswa terlibat langsung dalam proses menemukan jawaban terhadap persoalan yang ada dan langsung mempraktekkannya sehingga proses pembelajaran lebih efektif dan efesien. Perbandingan antara kelas eksperimen yang menggunakan model discovery learning dengan kelas kontrol yang menggunakan model pembelajaran konvensional dalam ranah kognitif $\mathrm{C} 1$ adalah, kelas eksperimen lebih meningkat daripada kelas kontrol karena pada kelas kontrol yang menggunakan model pembelajaran konvensional, siswa dominan mendengarkan penjelasan dari guru saja. Peneliti menjelasakan seluruh materi pembelajaran dan siswa mendengarkan apa yang dijelaskan oleh peneliti. Hal ini membuat siswa hanya menerima apa yang dijelaskan peneliti tanpa mencoba memikirkannya terlebih dahulu sehingga apa yang didengarkan mereka mudah lupa dan tidak tahan lama dalam ingatan mereka. Hal ini didukung oleh pendapat Febbivoyna dkk dalam jurnal penelitian yang berjudul pengaruh model discovery learning terhadap prestasi belajar fisika siswa kelas X SMA N 2 Batu yang menyatakan bahwa pada kegiatan inti pembelajaran, siswa yang dibelajarkan secara konvensional menerima semua informasi dari guru. Kegiatan inti pembelajaran cenderung monoton karena guru sering memberi penjelasan dan contoh soal. Hal tersebut menyebabkan siswa kurang dapat memaknai materi yang dipelajarinya.

Ranah kognitif C2 menuntut siswa agar dapat menunjukkan bahwa mereka telah memahami dan mempunyai pengertian yang memadai untuk mengorganisasikan dan menyusun materimateri yang telah diketahui. Selama penelitian peneliti mengidentifikasi masalah materi pembelajaran yang relevan dengan kehidupan sehari-hari supaya siswa lebih mudah memahami materi pelajaran yang disampaikan oleh peneliti. Hal ini didukung oleh jurnal penelitian yang menyatakan bahwa model discovery learning merupakan model pembelajaran yang mendorong siswa untuk mengajukan pertanyaan dan menarik kesimpulan dari prinsip-prinsip umum praktis contoh pengalaman. Hal yang menjadi dasar Jerome Bruner ialah pendapat Piaget yang menyatakan anak harus berperan secara aktif di dalam belajar di kelas. Bruner 
memakai cara dengan apa yang disebutnya discovery learning, yaitu murid mengorganisasikan bahan yang dipelajari dengan suatu bentuk akhir. Karakteristik model ini adalah siswa dapat mengorganisasi sendiri pengetahuan, memahami konsep, arti, dan hubungan melalui proses intuitif dan akhirnya sampai kepada suatu kesimpulan. Perbandingannya dengan kelas kontrol yang menerapkan model pembelajaran konvensional adalah, peneliti lebih banyak mencatat materi pembelajaran daripada menjelaskan kepada siswa bagaimana supaya siswa lebih paham dengan pelajaran. Akibatnya, siswa monoton mencatat apa yang dicatat guru di papan tulis tanpa paham dengan makna dari yang ditulisnya tersebut. Hal ini menyebabkan siswa tidak banyak memahami materi pelajaran yang disampaikan, sehingga menyebabkan tingkat pemahaman kelas eksperimen lebih tinggi dibandingkan tingkat pemahaman kelas kontrol.

Ranah kognitif C3 mencakup penggunaan suatu prosedur untuk menyelesaikan masalah atau mengerjakan tugas, hal ini sangat erat dengan pengetahuan prosedural. Selama penelitian di dalam kelas eksperimen, peneliti mengajari praktikum yang berhubungan dengan materi pembelajaran agar siswa memperoleh penerapan langsung dari materi yang kita ajarkan. Hal ini memang membuat siswa kreatif dan aktif dalam melakukan percoban serta pengolahan data, tetapi dalam sintaks model discovery learning, guru tidak bekerja banyak artinya guru tidak banyak menjelaskan materi pembelajaran. Proses pembelajaran berpusat pada guru tidak pada siswa. siswa harus dituntut lebih banyak bekerja secara mandiri. Inilah yang menyebabkan siswa tidak tergolong aktif dalam hal mengerjakan masalah atau mengerjakan soal. Pernyataan ini didukung oleh Sardiman dalam jurnal Siahaan dan Bakri, 2016, dalam mengaplikasikan model discovery learning guru berperan sebagai pembimbing dengan memberikan kesempatan kepada siswa untuk belajar secara aktif sebagaimana pendapat bahwa guru harus dapat membimbing dan mengarahkan kegiatan belajar siswa sesuai dengan tujuan. Inti dari penerapan discovery learning adalah penyajian pembelajaran yang tidak utuh dan modifikasi permasalahan oleh guru. Discovery learning sendiri merupakan model pembelajaran yang mengutamakan pemberian kesempatan seluasnya kepada siswa untuk mengeksplorasi secara aktif dalam setiap kegiatan pembelajarannya. Model ini menggeser paradigma teacher centered menjadi student centered. Peran guru justru menjadi lebih banyak, terutama dalam mendesain dan membimbing siswa agar pembelajaran dengan model discovery learning dapat terlaksana sesuai harapan, siswa membangun secara mandiri konsep dan pengetahuan. Perbandingannya dengan kelas kontrol yang menerapkan model pembelajaran konvensional adalah, peneliti membimbing siswa untuk mengerjakan latihan di depan kelas dan mengerjakan soal. Hal ini membuat siswa lebih cepat dalam mengerjakan soal dan latihan yang diberikan guru. Pernyataan ini sependapat dengan Febbivoyna dkk, dalam jurnal penelitian yang berjudul pengaruh model discovery learning terhadap prestasi belajar fisika siswa kelas X SMA N 02 batu yang menyatakan bahwa "pada akhir pembelajaran, siswa yang dibelajarkan secara konvensional diberi tugas yang harus dikumpulkan pada pertemuan berikutnya. Tugas berupa soalsoal latihan. Siswa dapat mengerjakan 
soal, karena siswa telah dilatih untuk mengerjakan soal-soal latihan.

Ranah kognitif C4 merupakan analisis menguraikan suatu permasalahan atau obyek ke unsur-unsurnya dan menentukan bagaimana saling keterkaitan antar unsur-unsur tersebut. Selama penelitian dalam kelas eksperimen, peneliti membuat perbandingan antara keterkaitan dua objek yang relevan dengan materi pembelajaran yang diajarkan oleh guru. Perbandingan ini dibuat agar siswa dapat melihat keterkaitan antara dua objek yang dibandingkan tersebut dan dapat memecahkan permasalahan yang terdapat dalam dua objek tersebut. Hal ini membuat siswa dapat menganalisis permasalahan yang ada serta mengerti bagaimana menentukan keterkaitan antara unsurunsur yang dibandingkan. Pernyataan ini didukung oleh pendapat Wenning, 2011 yang menyatakan bahwa "siswa yang belajar dengan model discovery learning akan melalui serangkaian tahap pembelajaran penemuan terstruktur sehingga siswa dapat lebih mengingat, memahami, menerapkan, dan menganalisis materi yang dipelajari. Tahapan pembelajaran yang sistematis, akan membantu siswa mengembangkan kemampuan berpikir secara mandiri daripada pembelajaran yang hanya mendengarkan atau membaca saja. Perbandingannya dengan kelas kontrol yang dibelajarkan dengan model pembelajaran konvensional adalah, peneliti dalam sintaks memberikan penjelasan materi kepada siswa tidak membuat perbandingan antar dua objek yang relevan dengan materi pembelajaran, sehingga siswa tidak paham dalam hal menganalisis unsur-unsur yang ada dalam kedua objek tersebut.

$$
\text { Ranah kognitif C5 adalah }
$$
kemampuan berfikir yang merupakan kebalikan dari proses berfikir analisis.
Sintesis atau evaluasi merupakan suatu proses yang memadukan bagian-bagian atau unsur-unsur secara logis, sehingga terbentuk menjadi suatu pola yang berstruktur atau berbentuk pola baru. Selama penelitian dalam kelas eksperimen, pada fase verivication (pembuktian) di kelas eksperimen, siswa diajak untuk berfikir kritis supaya dapat membuktikan apakah hasil yang diperoleh sesuai dengan teori yang ada. Apabila siswa sudah bisa membuktikan kesesuaian atau ketepatan antara hasil yang diperoleh dengan teori yang ada, maka siswa mampu mengevaluasi secara logis. Perbandingannya dengan kelas kontrol yang diterapkan dengan model pembelajaran konvensional adalah, pelajaran dominan berpusat pada guru, sehingga siswa tidak banyak berfikir yang menyebabkan mereka tidak dapat mengevaluasi materi pelajaran.

Hasil pengamatan yang dilakukan oleh observer diperoleh bahwa aktivitas belajar siswa mengalami peningkatan yang positif. Pertemuan I memiliki nilai aktivitas sebesar 43,46. Pelaksanaan penelitian pada pertemuan yang pertama, peserta didik masih belum terbiasa dengan model pembelajaran discovery learning sehingga intruksi dan motivasi diberikan peneliti kurang dimengerti oleh beberapa peserta didik. Peneliti terus memberikan intruksi dan arahan kepada siswa hingga siswa paham dan termotivasi melaksanakan tugas kelompok dan tanggung jawab mereka dalam pembelajaran. Pertemuan II memiliki peningkatan hasil belajar siswa menjadi 62,04 dan pertemuan III sebesar 83,33. Peneliti menjalankan sintaks model discovery learning. Sintaks yang pertama yaitu pemberian rangsangan, peneliti memberikan motivasi sebelum pembelajaran dimulai. Tahap selanjutnya yaitu identifikasi masalah, peneliti 
mengajak siswa untuk berfikir mengenai masalah-masalah yang relevan dengan kehidupan sehari-hari, pada tahap ini tingkat berpikir siswa mulai diuji. Tahap selanjutnya yaitu pengumpulan data, peneliti mengajak siswa untuk praktikum, dari data praktikum tersebut siswa diajak untuk mengumpulkan data. Tahap selanjutnya adalah pengolahan data, dimana data yang telah dikumpulkan oleh siswa diolah lagi berdasarkan prosedur yang tersedia. Tahap pambuktian yaitu, siswa membuktikan data yang diolah mereka dengan teori yang sebenarnya apakah sesuai atau tidak. Tahap terakhir adalah penarikan kesimpulan, pada tahap ini siswa menarik kesimpulan dari apa yang telah mereka kerjakan. Peneliti menjalankan sintaks tersebut pada setiap pertemuan dengan sub topik materi yang berbeda.

Beberapa temuan penelitian yang relevan dengan penelitian ini antara lain adalah Bahrani (2015) terdapat pengaruh pada hasil belajar siswa dengan menggunakan model discovery learning. Hal ini ditunjukkan dari nilai rata-rata pretes belajar siswa yang diajar sebesar 4,29 dan hasil postes sebesar 6,29. Model pembelajaran konvensional menunjukkan bahwa nilai rata-tara pretes siswa sebesar 4,03 dan postes sebesar 5,64. Peningkatan hasil belajar menggunakan model discovery learning lebih baik disebabkan model discovery learning ini dapat memotivasi siswa untuk lebih aktif saat pelaksanaan proses pembelajaran. Siswa saling berdiskusi dalam mengerjakan dan memecahkan permasalahan yang ada pada LKS saat siswa belajar dalam kelompok dan menjawab pertanyaan yang diajukan oleh guru pada materi momentum, impuls dan tumbukan terlihat siswa aktif dalam mengambil peran dalam pelaksanaannya.

\section{KESIMPULAN DAN SARAN}

\section{A. Kesimpulan}

Berdasarkan data hasil penelitian yang diperoleh dan analisa data serta pengujian hipotesis maka dapat disimpulkan bahwa penerapan model pembelajaran discovery dapat meningkatkan hasil belajar siswa. Model discovery yang diterapkan juga mengajak siswa untuk terlibat aktif dalam kegiatan pembelajaran, sehingga aktivitas belajar siswa meningkat dengan kategori aktif.

\section{B. Saran}

Bagi para peneliti selanjutnya yang ingin menggunakan model pembelajaran discovery learning sebaiknya mempersiapkan masalah-masalah dalam kehidupan sehari-hari yang menarik dan terkait pada materi pelajaran sehingga siswa akan tertarik mengikuti pelajaran.

\section{DAFTAR PUSTAKA}

Arikunto, S., (2013), Dasar-dasar Evaluasi Pendidikan, Bumi Aksara, Jakarta.

Aziz, A., Rokhmat, J., dan Kosim., (2015), Pengaruh Model Pembelajaran Berbasis Masalah Dengan Metode Eksperimen Terhadap Hasil Belajar Fisika Siswa Kelas X SMA N 1 Gunungsari Kabupaten Lombok Barat Tahun 2014/2015, Jurnal Pendidikan Fisika dan Teknologi 1(3) : 202

Damayanti, S.Q., dan Mahardika, I.K., (2016), Penerapan Model Discovery Learning Berbantuan Media Animasi Macromedia Flash disertai LKS yang Terintegrasi dengan 
Jujur Monasari Simatupang dan Pintor Simamora : Pengaruh Model Pembelajaran Discovery Learning Terhadap Hasil Belajar Siswa Pada Materi Pokok Momentum, Impusls Dan Tumbukan Kelas X Semester II Di SMA N 1 Pancurbatu TP. 2016/2017

Multirepresentasi $\quad r$ dalam
Pembelajaran Fisika di SMA,
Jurnal Penelitian $\quad$ \&
Pengembangan Pendidikan
Fisika 4(4) : 357-364

Dimyati, dan Mudjiono, (2013), Belajar dan Pembelajaran, Rineka Cipta, Jakarta.

Halliday, dan Resnick, (2010), Fisika Dasar Jilid 1, Erlangga: Jakarta

Hosnan, M., (2014), Pendekatan Saintifik dan Kotnekstual dalam Pembelajaran Abad 21, Ghalia Indonesia, Bogor.

Indarti, Nugroho, A., dan Syifa, N.H, (2016), Fisika untuk SMA Kelas $X$, Mediatama, Surakarta.

Joyce, B., dan Weil, M., (2009), Models of Teaching, Pustaka Pelajar, Yogyakarta.

Kadri, M. dan Rahmawati, M., (2015), Pengaruh Model Pembelajaran Discovery Learning terhadap Hasil Belajar Siswa pada Materi Pokok Suhu dan Kalor, Jurnal Penelitian \& Pengembangan Pendidikan Fisika 1(1) : 29-33

Mantik, Y.I., Wiyanto., dan Rusilowati, A., (2013), Pengembangan Perangkat Pembelajaran Gerak Lurus SMA Dengan Metode Eksperimen Bervisi Karakter, Innovative Journal of Curriculum and Educational Technology 2(1) : 152

Rusman, (2013), Model-model Pembelajaran, Raja Grafindo Persada, Jakarta.

Sagala, S., (2012), Konsep dan Makna Pembelajaran, Alfabeta, Bandung.

\section{Sanjaya, W., (2012), Kurikulum Pembelajaran Berorientasi Standar Proses Pendidikan, Prenada Media Group, Jakarta.}

Sarojo, G.A., (2002), Seri Fisika Dasar Mekanika, Salemba Teknika, Jakarta.

Siahaan, B.Z., dan Bakri, F., (2016), Pengembangan Model Pembelajaran Discovery Learning Pada Kegiatan Pembelajaran Fisika SMA, Jurnal Penelitian \& Pengembangan Pendidikan Fisika : 207-208

Slameto, (2013), Belajar dan Faktor-faktor yang Mempengaruhinya, Rhineka Cipta, Jakarta

Suardin., (2015), Penereapan Model Discovery Learning Pada Materi Sistem Pencernaan untuk Meningkatkan Hasil Belajar Siswa Kelas VIII SMP Negeri 2 Labuan, Jurnal Kreatif Tadulako Online 4(3) : 255

Sudjana, (2009), Metode Statistika, Tarsito, Bandung.

Supiyanto, (2007), Fisika untuk SMA Kelas $X I$, Phibeta, Jakarta.

Trianto, (2014), Mendesain Model Pembelajaran Inovatif Progresif, Kencana Prenada Media Group, Surabaya.

Yusuf, M. dan Wulan, A.R., (2015), Penerapan Model Pembelajaran Discovery learning Menggunakan Pembelajaran Tipe Shared dan Webbed untuk Meningkatkan Keterampilan Proses Sains, Jurnal Penelitian \& 
Jurnal Inpafi 6 (4) (2018) : 28-39

Pengembangan Pendidikan

Fisika 1(2) : 19-26 